
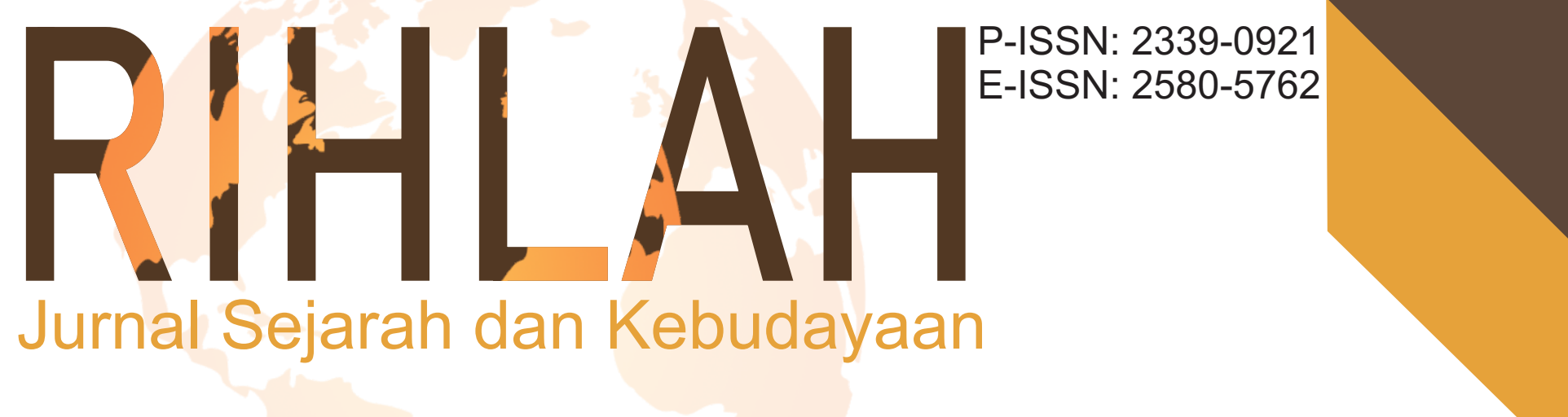

Article

Kebangkitan Kesultanan Ternate pada Era Reformasi 1998-2002 Rustam Hasyim, Oktosiyanti MT Abdullah, Siti Rahia H. Umar

Kondisi Politik Persia pada Era Dinasti Qajar 1796-1834 M Arafah Paramasto

Sultan Abdul Qahir dalam Pengembangan Islam di Bima Rahmat, Nurwahidah

Eksistensi Maccera Manurung dalam Perspektif Nilai Islam Sitti Fatimah Dwi Putri Islam dalam Tradisi Pernikahan Nuraeni

The Developments and Problems of Muslims in Australia Syamzan Syukur, Syamhi Muawwan, Syarifah Fauziah

Book Review

Historiografi Korupsi di Indonesia: Resensi Buku Korupsi dalam Miftakhuddin

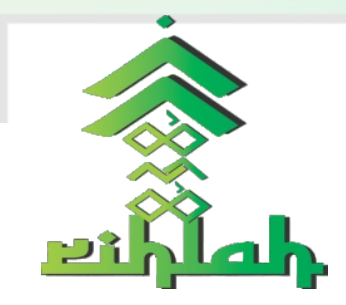




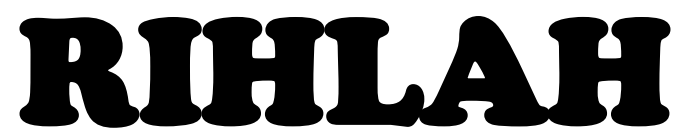

Jurnal Sejarah dan Kebudayaan

\begin{tabular}{|c|c|}
\hline Editor in Chief & Dr. Rahmat, M.Pd. \\
\hline Managing Editor & Mastanning, S.Hum, M.Hum. \\
\hline Editorial Board & $\begin{array}{l}\text { Nur Ahsan Syukur, S.Ag, M.Si. } \\
\text { Muh. Iqbal S.Hum, M.Hum. } \\
\text { Chaerul Munzir, S.Hum, M.Hum. } \\
\text { Lydia Megawati, S.Hum, M.Hum. } \\
\text { Muhammad Husni, S.Hum, M.Hum. } \\
\text { Zaenal Abidin, S.S., M.H.I. } \\
\text { Chusnul Chatimah Asmad, S.IP, M.M. } \\
\text { Muhammad Arif, S.Hum, M.Hum. }\end{array}$ \\
\hline Desain Grafis & Nur Arifin, S.IP. \\
\hline Secretariat & Safaruddin, S.Hum. \\
\hline Reviewers & $\begin{array}{l}\text { Prof. Dr. H. Abd. Rahim Yunus, M.A. } \\
\text { Prof. Dr. H. Ahmad M. Sewang, M.Ag. } \\
\text { Dr. Hj Syamzan Syukur, M.Ag. } \\
\text { Dr. Nasruddin Ibrahim. } \\
\text { Dr. Abd. Rahman Hamid. } \\
\text { St. Junaeda, M.Hum. } \\
\text { Dr. Syamhari, M.Pd. } \\
\text { Dr. A. Sukri Samsuri, M.Pd. }\end{array}$ \\
\hline
\end{tabular}

Alamat Redaksi dan Tata Usaha : Jurusan Sejarah dan Kebudayaan Islam Fakultas Adab dan Humaniora UIN Alauddin Makassar, Jln. Sultan Alauddin No. 36 Samata Gowa Tlp. 0411-841879 Fax. 0411-822140 (Kampus II) E.Mail. rihlah@uin-alauddin.ac.id

Jurnal Rihlah terbit dua kali dalam setahun, bulan Juni dan bulan Desember berisi kajian tentang Sejarah dan Kebudayaan, baik dari hasil penelitian maupun tulisan ilmiah lainnya.

Penyunting menerima tulisan yang belum pernah diterbitkan oleh media cetak lain. Naskah diketik spasi $1 \mathrm{~cm}$ pada kertas berukuran A4 dengan tulisan berkisar 12-23 halaman. Naskah yang masuk dievaluasi oleh Dewan Penyunting. Penyunting dapat melakukan perubahan pada tulisan yang dimuat untuk keseraganan format, tanpa mengubah maksud dan konten tulisan. 


\section{Daftar Isi}

Rustam, Oktosiyanti, Rahia

69-103

Kebangkitan Kesultanan Ternate pada Era Reformasi 1998-2002

Arafah Pramsto

104-125

Kondisi Politik Persia pada Era Dinasti Qajar 1796-1834

Rahmat, Nurwahidah

126-136

Sultan Abdul Qahir dalam Pengembangan Islam di Indonesia

Sitti Fatimah Dwi Putri

$.137-148$

Eksistensi Maccera Manurung dalam Perspektif Nili Islam

Nuraeni

$.149-158$

Islam dalam Tradisi Pernikahan

Syamzan, Syamhi, Syarifah 159-167

The Developments and Problems of Muslims in Australia

Miftakhuddin 168-172

Historiografi Korupsi di Indonesia: Resensi Buku dalam Silang

Sejarah Indonesia 


\title{
KEBANGKITAN KESULTANAN TERNATE PADA ERA REFORMASI 1998-2002
}

\author{
Rustam Hasim, Oktosiyanti MT Abdullah, Siti Rahia H. Umar \\ Universitas Khairun Ternate. \\ rustamhasyim@gmail.com \\ oktosiyantimtabdullah@gmail.com
}

\section{Abstract}

The elite revival of the Ternate Sultanate after the New Order illustrated how the palace group played a new role in staying in its position as a clan of power in the local sphere. In this case, the emergence of the elite of the Ternate Sultanate can be understood and interpreted in three respects. First, the rise of feudalistic power in the region to strengthen political position stemmed from cultural construction based on past history and genealogical similarities. Second, the individual revival of the Sultan of Ternate MudafarSyah in the name of the Sultanate institution as his political vehicle. Third, there is the elite desire of the Ternate Sultanate to be more institutionally accommodated into the formal government political stage. This reality shows the political participation of the Ternate Sultanate in the post-independence domain of local politics until now, is an important field of historical research. As a historical phenomenon, the process of dynamics of local politics like this is interesting to study, because the Sultan of Ternate has long been a part of the history of politics in North Maluku. In addition, there is an implicit message about how partial Indonesian political studies are if they only focus on the dynamics of national politics. In the case there are several national political issues which can initially be pursued from the region and vice versa.

Keywords: Ternate Sultanate, Sultan Mudafar Shah, Politics, Culture and Reform Era.

Kebangkitan elite Kesultanan Ternate pasca-Orde Baru mengambarkan bagaimana kelompok istana memainkan peran baru agar tetap berada pada posisinya sebagai pengenggam kekuasaan di ranah lokal. Dalam hal ini, apat dipahami bahwa ada tiga faktor yang menyebabkan kemunculan elit Kesultanan Ternate Pertama, bangkitnya kekuasaan feodalistik di daerah untuk memperkuat posisi politik bersumber dari konstruksi budaya yang berbasiskan pada sejarah masa lalu maupun kesamaan genealogis. Kedua, kebangkitan secara individual Sultan Ternate Mudafar Syah dengan mengatasnamakan institusi kesultanan sebagai kendaraan politiknya. Ketiga, adanya keinginan elite Kesultanan Ternate untuk lebih diakomodasikan secara institusional ke dalam panggung politik pemerintahan formal. Realitas tersebut menunjukkan partisipasi politik Kesultanan Ternate dalam ranah politik lokal pasca-kemerdekaan hingga kini, merupakan sebuah bidang penelitian sejarah yang penting. Sebagai sebuah fenomena historis, proses dinamika politik lokal seperti ini menarik untuk diteliti, 
karena telah sejak lama para Sultan Ternate menjadi bagian dalam sejarah perpolitikan di Maluku Utara. Selain itu, ada sebuah pesan implisit tentang betapa parsialnya kajian politik Indonesia bila hanya memfokuskan pada dinamika politik nasional saja. Pada hal ada beberapa persoalan politik nasional yang awalnya dapat diruntut dari daerah dan begitu pula sebaliknya.

Kata Kunci: Kesultanan Ternate, Sultan Mudafar Syah, Politik, Kebudayaan dan Era Reformasi.

\section{Kebangkitan Sultan Ternate}

Kemunculan kembali entitas politik masa lalu di tingkat lokal pada saat ini, dapat dipahami sebagai proses transisi politik yang berlangsung sejak berakhirnya rezim Orde Baru pada 1998. Proses politik berimplikasi pada pergeseran tata hubungan kekuasan antara institusi politik pusat dengan daerah. Pergeseran politik itu berjalan beriringan dengan menurunnya kredibilitas negara dan institusinya. Keadaan itu dijadikan momentum oleh kekuatan-kekuatan lama, termasuk kekuasaan feodalistik di daerah, untuk bangkit kembali memperjuangkan hak-hak politik di wilayah kekuasaannya dalam ranah politik lokal.

Sebelum kemerdekaan, menurut Ari Dwipayana, terdapat sekitar 250 daerah swapraja atau zelbestuurendelandschappen dalam teritori Indonesia. Sebagian besar dari daerah swapraja tersebut sama sekali tidak meninggalkan artefak atau bukti-bukti sejarah. Namun ada beberapa di antaranya yang masih eksis secara politik hingga sekarang seperti: Daerah Istimewa Yogyakarta, Kasuhunan Surakarta, Kesultanan Cirebon, dan Kesultanan Ternate. Beberapa keraton dapat dibangun dan tradisinya dihidupkan kembali serta menjalin kerjasama dalam Aliansi Keraton-keraton Nusantara.

Kembangkitan Kesultanan Ternate seiring dengan paradigma baru otonomi daerah menarik untuk dikaji. Dengan adanya regulasi UU No.22/1999, negara memberi pengakuan terhadap adanya hak asal-usul, kemudian dimanfaatkan secara baik oleh elite Kesultanan Ternate untuk membangun basis kekuasaanya atas klaim sejarah dan usul budaya. Munculnya Sultan Ternate Mudafar Sjah dipentas politik lokal sebagai usaha pemunculan kembali kekuatan-kekuatan feodal yang telah lama ada dengan menghidupkan lembaga-lembaga adat sebagai identitas kekuatan tradisional. Strategi ini merupakan upaya yang ditempuh elite Kesultanan Ternate agar tetap terakomodasikan secara institusional ke dalam panggung politik pemerintahan formal.

Pemekaran Maluku Utara menjadi propinsi baru berdasarkan UU No. 46/1999, melahirkan kontestasi politik antara elite kesultanan dan non kesultanan. Pembentukan Propinsi Maluku Utara ternyata diikuti dengan kebangkitan Kesultanan Ternate. Implikasi dari kebangkitan kesultanan tersebut adalah upaya sultan Ternate, Mudafar Sjah memfungsikan kembali instrumen kerajaan dalam rangka mencari legitimasi peran sultan. Persaingan elite kesultanan Ternate dan non kesultanan bukan hanya persoalan saja menyangkut perebutan kepentingan terhadap sumberdaya baru, melaingkan juga berkaitan dengan memori sosial kejayaan masa lalu. Tajamnya kepentingan politik dan perbedaan kepentingan 
dalam memperebutkan sumber-sumber kekuasaan ditingkal lokal merupakan pemicu lahirnya konflik pemelihan kepala daerah di Maluku Utara. Beberapa isu penting seperti; mengenai nama dan penempatan ibu kota propinsi, perebutan kursi gubernur, dan jabatan birokrasi pemerintahan baru kabupaten/kota. Semua itu menjadi isu yang strategis yang sengaja dibangun oleh elite lokal untuk mencari legitimasi atas kepentingannya.Dari berbagai persoalan tersebut, akan diuraikan dibawah ini.

\section{Ibukota Kabupaten ke Ibukota Propinsi}

Tuntutan masyarakat Maluku Utara untuk menjadi provinsi sendiri yang terpisah dari Maluku memeliki sejarah yang panjang. Upaya ini dirintis sejak pasca bubarnya Negara Indonesia Timur (NIT) dalam wadah Negara Indonesia Serikat (RIS) pada tanggal 17 Agustus 1950. Hal ini dimotori oleh Zainal Abidin Sjah (Residen Maluku Utara) dan Dewan Perwakilan Rakyat Daerah Sementara (DPRDS) Maluku Utara. Mereka membentuk sebuah badan yang disebut "Badan Musyawarah Rakyat Daerah Perbatasan Maluku Utara” untuk memperjuangkan daerah Maluku Utara menjadi daerah otonom tingkat I. Namun aspirasi tersebut ditangguhkan oleh Presiden Soekarno sampai kembalinya Irian Barat ke pangkuan ibu pertiwi.

Perjuangan Propinsi Maluku Utara kembali muncul ketika memasuki tahun 1964, disaat pemerintah pusat tidak merealisasikan janjinya untuk memekarkan Maluku Utara, setelah Papua bergabung ke Negara Kesatuan Republik Indonesia 1962. Di motori Bupati Maluku Utara M.S. Djahir, dan sejumlah tokoh masyarakat, pemuda, intelektual serta tokoh-tokoh partai politik seperti; Partindo, PSSI, NU, Partai Katolik dan Parkindo. Pada tanggal 23 Agustus 1964, mereka kemudian mengadakan musyawarah besar rakyat Maluku Utara. Dalam musyawarah tersebut dihasilkan beberapa keputusan yaitu: (1). Pengiriman sebuah delegasi ke Jakarta. (2).Penyusunan Buku Putih yang memuat seluruh argumentasi politik, sosial, ekonomi, budaya dan pertahanan keamanan mengapa Maluku Utara menuntut daerah tingkat I. dan (3). Mendesak Dewan Perwakilan Rakyat Daerah Gotong Royong (DPRD-GR) Kabupaten Maluku Utara untuk memperjuangkan pembentukan daerah tingkat I.

Untuk menindaklanjuti hasil keputusan tersebut, DPRD-GR kemudian mengeluarkan rekomendasi No.4/DPRD-GR/1965 yang memberi dukungan atas upaya pembentukan provinsi Maluku Utara, dengan membentuk sebuah wadah yang dinamakan "Badan Pemekaran Daerah Tingkat I (BAPPERAN) Maluku Utara. Pada 1967 DPRDGR mengerimkan delegasike Jakarta guna menyampaikan aspirasi masyarakat Maluku Utara. Namun dengan adanya pergantian dari rezim Presiden Soekarno ke Pemerintahan Soeharto mengakibatkan upaya-upaya tersebut tidak terealisasi.

Memasuki pemerintahan Soeharto (Orde Baru), upaya untuk melakukan tingkat I tidak lagi dipermasalahkan. Hal tersebut disebabkan kebijakan politik di era Orde Baru lebih berorintasi pada pembangunan ekonomi dibandingkan politik.Untuk merealisasikan hal ini rezim Orde Baru menerapkan bebrapa 
kebijkan, pertama, melakukan stabilisasi dan pembangunan ekonomi yang berorientasi pada pertumbuhan.Kedua, melakukan penataan politik dengan harapan terbentuknya suatu sistem politik yang kondusif bagi pilihan kebijaksanaan ekonomi. Oleh Presiden Soeharto menggunakan jargon "pembangunan" untuk mengemas hal itu.Dengan demikian, arah penataan politik yang dilakukan pada periode awal pemerintahan rezim Orde Baru adalah menyederhanakan struktur kepartaian, baik dan segi jumlah, pola dukungan, basis massa, maupun aliran serta ideologi yang dianut bagi partai-partai. Dengan berbagai kebijakan tersebut tampaknya tidak bersahabat dan menutup peluang bagi Maluku Utara untuk memperjuangkan status provinsinya.

Berakhirnya rezim Orde Baru pada tahun 1998, dinamika politik Indonesia memasuki era baru. Dalam waktu yang relatif singkat, Indonesia mengalami desentralisasi secara besar-besaran. Moment tersebut kemudian dimanfaatkan tokoh-tokoh Maluku Utara seperti; Sultan Ternate Mudaffar Syah, Asisten I Provinsi Maluku Thaib Armayin, Bupati Halmahera Tengah Bahar Andili, dan Walikota Ternate Syamsir Andili, berinsiatif untuk memperjuangkan Maluku Utara menjadi sebuah propinsi defenitif.

Untuk menindaklanjuti gagasan tersebut, Pemerintah Daerah Kabupaten Maluku Utara kemudian membentuk team yang dinamakan "team sembilan" yang di pimpin oleh Abdullah Assagaf Bupati Maluku Utara.Beranggotakan sejumlah perwakilan dari Pemerintah Kabupaten Halmahera Tengah dan DPRD Kabupaten Maluku Utara. Team ini kemudian melakukan konsultasi dengan DPR-RI dan Pemerintah Pusat. Hasil dari konsultasi team tersebut, akhirnya Pemerintah Pusat merespon dengan membentuk team yang terdiri atas Depdagri dan Komisi II DPRRI. Team ini kemudian menilai syarat-syarat formal yang harus dipenuhi sebuah provinsi baru termasuk mengenai nama dan kedudukan ibukotanya.

Persoalan pembentukan nama dan kedudukan ibukota propinsi mendorong Kesultanan Ternate, memprakarsai diadakannya seminar pada tanggal 21 November 1998. Seminar tersebut dihadiri Sultan Ternate Mudafar Sjah, Bahar Andili (Bupati Halmahera Tengah), Samsir Andili (Walikota Ternate), Abdullah Assagaf (Bupati Maluku Utara) dan Dandim 1501 Ternate. Seperti halnya yang terjadi dibanyak daerah, persoalan pemekaran wilayah di Kepulauan Maluku menimbulkan perdebatan yang serius antara elite lokal. Perdebatan yang muncul di kalangan elite tersebut terutama berkaitan dengan nama propinsi hasil pemekaran dan berkaitan dengan pembagian kekuasaan/jabatan didaerah yang baru dimekarkan.

Persoalan pertama yang berkaitan dengan pemekaran wilayah di Kepulauan Maluku berkaitan dengan nama propinsi hasil pemekaran. Usulan dari kalangan non kesultanan bahwa propinsi Maluku akan dimekarkan menjadi dua propinsi dengan nama propinsi Maluku Utara dan Propinsi Maluku Selatan. Perdebatannya hanyalah pada istilah "Maluku Selatan" yang identik dengan kelompok RMS. Maka dari itu, kebijakan yang diambil untuk Maluku wilayah selatan tetap menggunakan nama Propinsi Maluku, sedangkan Maluku bagian utara dinamakan dengan Propinsi Maluku Utara. 
Sementara dari Kesultanan Ternate menginginkan nama Maloku Kie Raha dan kedudukan ibukota propinsi tetap berada di Kota Ternate atau di wilayah Halmahera Barat (Jailolo dan Sidangoli). Secara historis daerah tersebut merupakan wilayah kekuasaan Kesultanan Ternate.Bahkan kelompok ini juga menginginkan propinsi ini memeliki status daerah istimewa seperti di berlakukan di Daerah Istimewa Yogyakarta (DIY) atau Daerah Istimewa Banda Aceh.Akhirnya seminar tersebut, merekomendasikan kepada pemerintah RI untuk menetapkan nama propinsi yang dimekarkan adalah Maloku Kie Raha dan Ternate sebagai ibukotannya. Untuk mengawal agenda tersebut, pihak Kesultanan Ternate kemudian membentuk lembaga adat yang dinamakan Generasi Muda Sultan Babullah (Gemusba), sebagai media perjuangannya.

Gayungpun bersambut, dalam rangka mendukung rekomendasi Kesultanan Ternate. Para elemen Pemuda dan mahasiswa Ternate yang tergabung dalam Himpunan Mahasiswa Maluku Kie Raha (HIPMA MKR) dan Forum Studi Pemuda Kreatif Maluku Kie Raha (FSPKMKR) dan Generasi Muda Sultan Babullah (GEMUSBA), mengelar seminar nasional pada 1 Desember 1998. Salah satu keputusan seminar tersebut mengusulkan kepada pemerintah pusat untuk menetapkan Maloku Kie Raha sebagai nama propinsi dan Ternate sebagai ibukotanya.

Kembangkitan kembali kesultanan-kesultanan di Maluku Utara pada era reformasi mengambarkan bagaimana kelompok elite istana tampil dan memaingkan peran-peran baru dalam perpolitikan di Maluku Utara. Kebangkitan kembali empat Kesultanan di Maluku Utara dianggap menjadi ancaman politik bagi kelompok non kesultanan.Mengingat agenda terdekat adalah pemilihan Gubernur Maluku Utara. Menurut Gerry van Klinken, kembalinya para sultan di Maluku Utara dalam pentas gerakan komunitarian dalam politik lokal pasca Orde Baru adalah upaya membangun kembali hegomoni politik dengan merepresentasikan diri sebagai representasi adat, identitas, dan nilai-nilai lokal yang ada di Maluku Utara.

Nama perumahan dan kedudukan ibukota propinsi antara kedua kubu tersebut, bukan hanya berhubungan dengan soal politik melaingkan kepentingan ekonomi. Daerah-daerah yang ditetapkan oleh pihak Kesultanan Ternate yakni Pulau Ternate atau daerah Halmahera Barat (Jailolo dan Sidangola) merupakan aha kolano (tanah Sultan), sehingga ketika ditetapkan menjadi ibukota propinsi, tentu mendatangkan sumber kemakmuran bagi rakyat yang berada daerah kekuasaanya. Begitu pula sebaliknya kelompok non kesultanan yang menginginkan Tidore sebagai ibukota propinsi Maluku Utara memiliki motif yang sama pula yakni penguasaan basis ekonomi.

Dari sinilah terbentuk polarisasi kekuatan kelompok elite di Maluku Utara kedalam dua kubu. Kubu pertama adalah "Kubu Ternate" yang terdiri atas; Sultan Ternate Mudafar Syah, Sultan Tidore Djafar Dano Yunus, Sultan Bacan Gahral Syah, dan Sultan Jailolo Mahmud Syah. Sedangkan kubu yang kedua adalah "Kubu non kesultanan" yang terdiri dari Sekwilda Maluku Utara Taib Armain, Bupati 
Maluku Utara Abdullah Asaggaf, Wali Kota Ternate Syamsir Andili, dan Bupati Halmahera Tengah Bahar Andili.

Pembentukan aliansi tersebut membuat perdebatan nama dan kedudukan propinsi yang berlarut-larut. Akhirnya mendorong Menteri Dalam Negari dan Otonomi Daerah Ryas Rasyid atas nama pemerintah pusat dan DPR-RI menetapkan UU. No. 46 tahun 1999, tertanggal 27 Oktober 1999 tentang pemekaran Propinsi Maluku Utara dan menetapkan Sofifi (Halmahera Tengah) sebagai ibukotanya. Sehubungan dengan infrastrukur belum tersedia, maka untuk sementara waktu Ternate ditetapkan sebagai ibukota transisi Propinsi Maluku Utara.

Penetapan Ternate sebagai ibukota transisi propinsi Maluku Utara. Maka dengan sendirinya perdebatan tentang nama dan kedudukan ibukota provinsi telah selesai. Seluruh komponen masyarakat Maluku Utara termasuk pihak nonkesultanan dapat menerima keputusan Pemerintah Pusat. Sementara itu, Bupati Halmahera Tengah Bahar Andili, sekaligus tokoh non kesultanan mendapat tekanan dari masyarakatnya sendiri, karena gagal dalam mewujudkan ambisinya menjadikan Tidore sebagai ibukota propinsi. Masyarakat menekan Bupati Halmahera Tengah tersebut untuk mempertangungjawabkan dana daerah konon dipakai untuk mempromosilkan Tidore sebagai ibukota transisi Propinsi Maluku Utara.

\section{Pencalonan Sultan Ternate Sebagai Gubernur Maluku Utara}

Penerapan otonomi daerah telah membuat pergumulan politik lokal menarik untuk dicermati. Salah satu "produk" dari reformasi adalah pemekaran wilyah di Indonesia. Salah satu diantaranya pemekaran propinsi Maluku Utara (propinsi ke-27) berdasarkan UU No. 46 tahun 1999. Kelahiran UU tersebut juga dipandang merupakan peluang untuk mewujudkan aspirasi yang sempat terhambat akibat politik sentralistik rezim Orde Baru yaitu keinginan untuk memeliki pemimpin lokal yang disepakati oleh rakyat. Alasan utama adalah bahwa "putra daerah" selama periode pemerintahan Soeharto tidak pernah mendapat kesempatan untuk memimpin daerahnya.Gubernur dan Bupati selalu ditunjuk oleh pusat, sehingga kebijakan mereka tidak mengakar di kalangan masyarakat setempat.

Pengalaman historis itulah kemudian mendorong elite kesultanan mengambil bagian dalam "gerakan daerah" untuk menuntut Maluku Utara menjadi provinsi sendiri lepas dari Maluku. Ketika pemerintah pusat (Pemerintahan Habibie) merespon dengan lahirnya UU No. 46 1999, maka Sultan Ternate Mudafar Sjah tidak hanya menjadi simbol, tetapi ingin berkuasa sebagai gubernur. Kebangkitan elite Kesultanan Ternate pasca Orde Baru, menurut Gerry van Klinken dilatar belakangi beberapa hal, pertama, kebangkitan simbolik dari sebuah entitas yang pernah diruntuhkan dan dibiarkan hancur pada periode Orde Lama dan Orde Baru. Sejak Orde Lama hingga Orde Baru, elite Kesultanan Ternate tidak menjadi bagian penting dalam bidang pemerintahan (eksekutif) baik jabatan Bupati ataupun Gubernur. 
Kedua, kebangkitannya secara individual dengan mengatasnamakan kesultanan sebagai kendaraan politiknya. Keinginan ini sebagai sbagai upaya membangkitkan kejayaan Kesultanan Ternate dan tetap berada pada posisinya sebagai pengenggam kekuasaan diranah lokal.Ketiga, tidak bisa dilepaskan dari keinginan kesultanan diberbagai daerah di Indonesia untuk lebih diakomodasi secara institusional kedalam panggung politik pemerintahan formal.Keempat, mereka dapat tampil dalam bentuk naiknya pamor dari lembaga-lembaga adat dalam kerangka regulasi UU No. 22 tahun 1999, dimana negara memberi pengakuan terhadap adanya hak asal-usul.Pengakuan terhadap hak asal-usul ini, kemudian dimanfaatkan secara baik oleh Kesultanan Ternate untuk membangun kembali basis kekuasaannya atas klaim sejarah dan identitas budaya.

Berdasarkan hasil pemilu tahun 1999, Partai Golongan Karya (P-Golkar) unggul.Dengan 17 kursinya sehingga mendominasi DPRD Provinsi Maluku Utara yang keanggotaannya berjumlah 45.Di urutan kedua adalah Partai Demokrasi Indonesia Perjuangan (PDIP) dan Partai Persatuan Pembangunan (PPP), masingmasing dengan 7 (tujuh) kursi.Selain ketiga partai itu terdapat 8 (delapan) parpol lain yang ada di DPRD Provinsi, yaitu Partai Demokrasi Kasih Bangsa (2 kursi), dan masing - masing 1 (satu) kursi yaitu: (1). Partai Amanat Nasional; (2). Partai Kebangkitan Bangsa); (3). Partai Demokrasi Indonesia-Budi Hardjono; (4). Partai Persatuan; (5). Partai Bulan Bintang; (6). Partai Keadilan; dan (7). Partai Krisna.

Pemilihan Gubernur Maluku Utara yang direncanakan dilangsungkan pada Nopember 2000, merupakan pemilihan gubernur pertama dalam suasana multipartai, dimana partai-partai baru bermunculan setelah kejatuhan era Soeharto.Walaupun secara nasional suara Golkar mengalami penurunan, namun masih kuatnya dukungan rakyat terhadap Sultan Ternate, sekaligus sebagai ketua DPD II Golkar sehingga perolehan suara Golkar tetap pada posisi single majority tanpa terpengaruh dengan perubahan politik nasional.

Sebelum proses penjaringan pasangan bakal calon dimulai tahun 2000, masing-masing partai telah melakukan proses penjaringan didalam mencari figur masing-masing.Di internal partai Golkar terdapat dua figur yakni Abdul Gafur dan Sultan Mudafar Syah. Dengan kapasitasnya sebagai Sultan Ternate, ketua DPRD Kabupaten Maluku Utara, dan Ketua DPD Golkar, mendorongnya mencalonkan diri sebagai Gubernur Maluku Utara. Akan tetapi dari awal pengajuan nama bakal calon gubernur iklim persaingan sudah terasa. Abdul Gafur yang mantan Menteri Pemuda dan Olahraga dan mantan ketua DPP Golkar, dan kedekatan emosional para petinggi Golkar seperti Akbar Tanjung sebagai ketua DPP Golkar DPP Golkar diprediksi Abdul Gafur memenangkan persaingan tersebut. Keputusan akhir dari DPP Golkar menunjuk nama Abdul Gafur dan Yamin Tawary (anggota DPR Pusat dari Golkar) dalam rekomendasinya tertanggal 22 Desember 1999 yang harus diperjuangkan oleh Golkar sebagai calon Gubernur. Keputusan DPP Golkar ini menyebabkan kubu Sultan Mudafar Sjah kecewa.

Intervensi dewan pimpinan pusat (DPP), Golkar dalam mendudukan atau sebaliknya, menggusur, seseorang untuk menjadi bakal cagub/cawagub.Tampaknya cukup kuat pengaruhnya dalam kasus kegagalan Sultan Mudafar Sjah sebagai calon 
Gubernur Maluku Utara dari partai Golkar.Menurut ketentuan UU No. 22 tahun 1999, gubernur adalah pegawai pusat dan sekaligus daerah.Dalam menjalangkan tugas dan kewenangan sebagai kepala daerah, gubernur bertangungjawab kepada DPRD propinsi.Namun dalam kedudukan sebagai wakil pemerintah gubernur berada dibawah dan bertangungjawab kepada presiden.Posisi gubernur yang dualistik (sebagai alat Pemerintah Pusat sekaligus alat Daerah), memungkinkan Presiden dan Menteri dalam Negeri untuk melakukan intervensi dalam tahap konsultasi oleh DPRD Provinsi, mengenai bakal calon.

Merasa terzalimi dan tidak diakomodir oleh partai Golkar dalam pencalonan dirinya sebagai Gubernur Maluku Utara. Sebagai Sultan Ternate dan ketua DPD Partai Golkar Kabupaten Maluku Utara, ia memerintahkan kepada semua masyarakat adat dan elemen yang bernaung di bawah Partai Golkar, untuk mengundurkan diri. Pada tanggal 24 Desember 1999, Sultan Mudafar Syah menyatakan sikap resmi keluar dari Partai Golkar. Keluarnya Sultan dari partai Golkar ditandai dengan pembakaran sejumlah atribut partai seperti; bendera, kaos, topi maupun atribut lain yang dipusatkan di kadaton Ternate.

Tidak terakomodirnya Sultan Mudafar Syah dari DPP Partai Golkar dalam pencalonannya sebagai Gubernur Maluku Utara, selain intervensi pusat, adalah ia termasuk orang Golkar yang punya kedekatan dengan rezim Orde Baru. Apalagi pada masa itu, reformasi masih dirasakan oleh masyarakat sebagai sebuah gerakan "peninjauan" atas kekuasaan Orde Baru.Selain itu juga dipengaruhi "ketakuatan" kembali berkuasanya kekuasaan tradisional di panggung politik formal. Tak heran nuansa penolakan juga dihubungkan tentang masa lalu "cacat historis" para sultan Ternate, pada awal kemerdekaan telah mendukung pembentukan Negara Indonesia Serikat (RIS) dan tidak punya integritas terhadap negara kesatuan RI. Di samping itu, bagi sebagian masyarakat Maluku Utara menilai Sultan Mudafar Syah sebagai tokoh antagonis.

Sejak pengunduran dirinya dari ketua DPD Partai Golkar Kabupaten Maluku Utara. Pada saat yang sama, pasukan keamanan kesultanan (Gemusba), membuat kekacauan dengan menyerang beberapa perkampungan di bagian Ternate Selatan yang dianggap bertangungjawab atas tidak terakomodirnya Sultan Mudafar Sjah sebagai calon gubernur. Akibat konflik tersebut Sultan dan keluarganya terpaksa mengungsi ke Manado, sehingga jabatannya sebagai Ketua DPRD Maluku Utara di copot. (mengenai konflik Maluku Utara akan dijelaskan kemudian).

Pada tahun 2001 Sultan Ternate Mudafar Sjah, tkembali dari tempat pengungsiannya ke Ternate. Tujuannya dapat mengikuti perkembangan pemilihan kepala daerah pertama kali di Maluku Utara.Sejak kehadirannya di Ternate, DPRD Maluku Utara telah dua kali melakukan pemilihan Gubernur Maluku Utara. Dalam pemilihanpada tanggal 5 Juli 2001 dimenangkan oleh Abdul Gafur dan Yamin Tawari, namun kemenangannya di anulir karena di duga melakukan politik uang (money politik).Di samping itu pencalonan Abdul Gafur sebagai calon Gubernur Maluku Utara tidak mendapat restu dari pemerintahan Megawati. Tidak adanya dukungan dukungan politik Presiden Megawati merupakan faktor 
determinan yang mengakibatkan dibatalkannya kemenangan Abdul Gafur dan Yamin Tawari sebagai pasangan Gubernurdan Wakil Gubernur Maluku Utara.

Begitupula dalam pemilihan tahap II, yang dilaksanakan pada tanggal 28 Oktober 2001. Pemilihan tahap II itu, hanya diikuti dua paket, yaitu; pasangan pertama Arifin Raimadoya dan Amin Drakel yang diusung oleh Fraksi PDI-P. Pasangan kedua Thaib Armaiyn dan Yamin Waisale yang diusulkan oleh fraksi Reformasi. Pemilihan ulang ini akhirnya dimenangkan oleh Thaib Armaiyn dan Yamin Waisale sebagai gubernur dan wakil gubernur. Akan tetapi kemenangan Thaib Armaiyn dan Yamin Waisale dalam pemelihan tersebut, dibatalkan atau di tolak oleh Mendagri karena berlangsung tanpa izin dari pemerintah pusat.

Sebagai tindak lanjut atas gagalnya pemilihan tahap II pada tanggal 7 Maret 2002. DPRD Maluku Utara untuk ketiga kalinya melakukan pemilihan gubernur dan wakil gubernur pada tanggal 28 Oktober 2002.Pada pemilihan tahap III ini, Sultan Mudafar Sjah tampil kembali mencalonkan dirinya sebagai Wakil Gubernur melalui fraksi PPP berpasangan dengan Abdul Gafur. Pencalonan Abdul Gafur dan Mudafar Sjah dalam daftar calon Gubernur dan Wakil Gubernur telah disetujui oleh semua fraksi di DPRD Maluku Utara, terkecuali fraksi Golkar telah menyatakan sikap politik tidak akan mengikuti pemilihan ulang sebelum ada keputusan dari presiden mengenai penyelesaian kasus kemenganan Abdul Gafur pada pemilihan pertama.

Walaupun pencalonan Abdul Gafur dan Mudafar Sjah telah disetujui semua fraksi di DPRD Maluku Utara.Namun kedua pasangan itu ditolak oleh Mendagri karena tidak memenuhi persyaratan adiministrif. Pencoretan nama Abdul Gafur dan Mudafar Sjah oleh Mendagri sehingga tidak dapat diikutsertakan dalam pemilihan tersebut. Sebagai tokoh masyarakat Maluku Utara dan juga Sultan Ternate, Mudafar Sjah mengaku kecewa terhadap Menteri Dalam Negeri yang mencoret namanya untuk dipasangkan dengan Abdul Gafur.

Walaupun ada ketidakpuasaan sebagaian elite dan masyarakat, pemilihan tahap III pada tanggal 28 Oktober 2002 tetap dilakukan.Setelah melalui tahapantahapan pembentukan panitia pemilihan hingga penetapan pasangan bakal calon. Dari 30 yang mencalongkan diri sebagai Gubernur Maluku Utara hanya tiga bakal calon yang ditetapkan oleh Mendagri sebagai pasangan calon Gubernur dan Wakil Gubernur Maluku Utara berdasarkan surat Mendagri No. 121.17/2360/2002 yaitu pasangan Thaib Armain-Yamin Tawary, Sudjud Sirajuddin-Madjid Abdullah, dan Taib Armain-MAdjid Abdullah. Dalam pemilihan tersebut Thaib Armaiyn dan Madjid Abdullah (Fraksi PDIP) memenangkan pemilihan sebagai Gubernur dan Wakil Gubernur Maluku Utara pertama. Dengan terpilihnya pasangan Thaib Armaiyn dan Madjid Abdullah (non kesultanan), maka berakhirlah keinginan Sultan Ternate Mudafar Syah untuk diakomodasikan secara institusional dalam panggung politik pemerintahan formal di Maluku Utara.

\section{Reformasi dan Angin Perubahan}

Gagalnya Sultan Mudafar Syah dalam pencalonannya sebagai Gubernur Maluku Utara ternyata tidak menyurutkan untuk berkiprah dalam pentas politik. 
Kekecewaannya terhadap Golkar, kemudiaan diarahkan untuk mendukung dan bergabung dengan partai Demokrasi kebangsaan (PDK) sebagai penasehat Wilayah Provinsi Maluku Utara pada 24 Desember 2002.

Di pakainya PDK sebagai mesin politiknya yang baru, ternyata membuahkan hasil sebagai pemenang kedua Pemilu legislatif 2004 di Kota Ternate. Melalui pertai inilah kemudian mengantarkannya menjadi anggota DPRRI periode 2004-2009, dan Permaisurinya Nita Budi Susanti sebagai anggota DPD mewakili Maluku Utara dan sejumlah bangsawan menjadi anggota Legislatif tingkat I dan II.

Selain itu, dalam membangun kembali hegemoni politiknya strategi yang digunakan tidak hanya melalui partai politik, akan tetapi juga lewat penguatan politik kebudayaan atau melakukan perluasan jaringan kekerabatan dengan memberikan gelar kehormatan pada pejabat atau mantan pejabat baik pusat maupun daerah. Selain melakukan perluasan jaringan kekerabatan dengan memberikan gelar kehormatan pada pejabat atau mantan pejabat baik pusat maupun daerah adalah perluasan pengaruh melalui forum-forum keraton se Nusantara (FKKN). Perluasan pengaruh melalui aliansi keraton se-Nusantara merupakan cara keraton untuk memperkuat posisi tawar keraton untuk berhadapan dengan negara.

Salah satu agenda yang dimiliki oleh aliansi tersebut adalah kejelasan tanahtanah bekas swapraja yang diambil alih oleh negara pada pemerintahan Soekarno. Misalnya Pada forum Komunikasi Keraton-Keraton se Indonesia (FKKKI) III di Kutai Kalimantan Timur, tahun 2002, Sultan Ternate Mudafar Sjah mengeluarkan pernyataanya membangkitkan kembali kerajaan-kerajaan yang tanah adatnya diambil oleh negara, dengan mengatakan. "Kami para sultan dan raja memeliki konsesi atas hutan, tambang dan lain sebagainya karena semua itu adalah hak tradisional kami. Sekarang setelah merdeka, para sultan secara ironis telah dirampok habis hak-hak mereka. Para sultan dimiskinkan, sementara konglomerat bertambah kaya. Saat kami kembali kerumah masing-masing, kami akan berjuang menuntut hak-hak yang telah dirampas pemerintah"

Atas nama adat inilah sultan Ternate disatu sisi menegaskan adanya ketidakadilan di masa lalu yang harus diatasi, disisi lain sebagai jalan untuk mengamankan posisi-posisi yang menguntungkan dalam perebutan kekuasaan di daerah pasca Soeharto. Forum komunikasi keraton dijadikan sebagai wadah menentang pemerintah dengan jumlah tuntutan yang keras, termasuk pengembalian seluruh tanah adat kepada komunitas masyarakat adat dan penghapusan organ-organ Orde Baru di tingkat pemerintahan desa.Dalam forum itulah Sultan Ternate Mudafar Sjah, terpilih sebagai ketua umum Forum Komunikaasi dan Informasi Keraton se Nusantara.

\section{Festival Legu Gam (Ulang Tahun Sultan) Sebagai Pusat Budaya dan Politik}

Pada masa pemerintahan Sultan Mudafar Sjah, selain menjadikan istana sebagai pusat politik, juga sebagai pusat budaya. Sebagai pusat kebudayaan maka diselenggarakan upacara-upacara istana, seperti; Legu Gam (ulang tahun sultan), 
Kololi Kie (mengelilingi gunung), Fere Kie (mendaki gunung), Isra Miraj, dan Maulid Nabi. Strategi ini diyakini akan membawa dampak yang besar bagi keberadaan istana sebagai pusat anutan.Kondisi inilah elite kesultanan secara trampil memainkan klaim sebagai pusat kebudayaan Maluku Utara. Klaim itulah yang menyebabkan negara dalam hal ini Kementerian Parawisata memilih berkerjasama dengan istana sebagai wujud perhatian pemerintah pada kebudayaan lokal.

Diantara sekian banyak upacara yang diselengarakan oleh kadaton Ternate adalah upacara Legu Gam mempunyai bobot politik yang cukup penting. Perayaan ini lakukan setiap tahun pada bulan April untuk merayakan hari ulang tahun Sultan Mudafar Syah yang jatuh pada tanggal 12 April dan pelaksanaanya sebulan penuh. Secara historis perayaan Legu Gam telah dilakukan sejak abad ke XVI pada masa pemerintahan Sultan Ternate ke-26 Babullah. Namun pelaksanaannya pada saat itu dilakukan di dalam istana dan hanya dihadiri para kalangan bangsawan dan bobato akhirat (ulama kerajaan). Dalam upacara tersebut para bobato akhirat bertugas membacakan doa kiye (doa kesalamatan), sebagai wujud rasa sukur atas karunia Tuhan berupa limpahan rezeki, keselamatan, kesehatan bagi seluruh rakyat dan mendatangkan kejayaan bagi negara.

Memasuki tahun 1994, Sultan Mudafar Sjah mengeluarkan iddin kolano (fatwa sultan) bahwa upacara Legu Gam di laksanakan pada tempat terbuka alunalun timur istana (lapangan Salero), dengan bobot yang lebih meriah atau dilakukan secara besar-besaran. Sebagai wujud pelastarian budaya Ternate, sehingga diharapkan memperkaya khasanah budaya nasional, sekaligus menjadi perekat sistem nilai dalam kehidupan masyarakat.

Perayaan Legu Gam memeliki dimensi politik sangat menonjol, namun perayaan itu sendiri menunjukan adanya kreatifitas pada seni tari dan simbolsimbol lainnya, seperti bahasa, pakaian tata cara yang berhubungan dengan seremoni ritual. Perayaan Legu Gam juga dipakai sebagai strategi untuk memperluas jaringan kekerabatan. Dalam setiap pergelaran para tamu negara atau duta-duta besar dari negara asing menerima gelar kehormatan.Kehadiran mereka dalam perayaan iitu sebagai bagian dari kerabat tentu memberikan keuntungan politis bagi mereka, terutama dihadapan masyarakat tradisional.Namun bagi istana, kehadiran politisi dan birokrat juga bisa menaikan pamor istana secara politis.Dengan memanfaatkan relasi yang telah terbangun untuk mendapatkan akses pada sumberdaya ekonomi maupun politik yang dimiliki oleh politisi dan birokrat. Begitu pula para politisi mungkin berharap dengan gelar kebangsawanan yang mereka dapatkan dari istana akan membuka ruang bagi mereka untuk mendapatkan dukungan pemilih tradisional. Strategi itulah disebut "politik kekerabatan”.Politik kekerabatan ini diambil karena dua hal.Pertama, mengubah kekuatan politik berpegaruh dan potensial menjadi musuh menjadi kawan atau kerabat. Kedua, untuk mendapatkan pihak-pihak yang menguntungkan secara ekonomi maupun politik.

Pemberian gelar kebangsawanan merupakan strategi politik untuk memperkuat posisi istana ditengah masyarakat. Dengan diberikan gelar, maka kesemua elemen sosial politik secara resmi menjadi bagian dari kerabat Kesultanan 
Ternate.Menjadi kerabat tentu saja mempunyai konsekuensi logis pada istana baik secara ekonomi, politik maupun budaya.

Apa yang dilakuka Sultan Mudafar Syah dalam perayaan Legu Gam sebagai wadah untuk tetap menjadikan istana sebagai pusat politik sekaligus pusat kebudayaan. Sebagai wadah politik, perayaan Legu Gam merupakan sintesa politik yang telah dikembangkan telah lama (sebelum kemerdekaan) dari satu generasi ke generasi selanjutnya dengan tujuan mencari legitimasi kekuasaan tradisional. Kehadiran para utusan dari daerah dalam menghadiri perayaan hari ulang tahun sultan mengandung arti bahwa mereka mengakui kekuasaannya. Di sisi lain, upacara itu erat sekali hubungannya dengan ekonomi. Penggarapannya dilakukan dengan mengejar keindahan dan kemegahan dengan tujuan dapat menjaring wisatawan agar dapat menopang pembangunan sebagai sumber ekonomi.Keuntungan ekonomi yang diperoleh dari acara Legu Gam digunakan untuk memelihara ikatan dengan pengikut tradisional mereka. Surplus ekonomi juga digunakan untuk menyelengarakan upacara-upacara besar yang hegemoni dalam arena kultural, seperti upacaraKololi Kie (mengelilingi gunung), dan Fere Kie (mendaki gunung). Dengan demikian, kapasitas material yang cukup digunakan secara kreatif untuk membangun simbol-simbol kemegahan kultural yang pada akhirnya mengukuhkan mereka sebagai pusat anutan.

\section{Simpulan}

Runtuhnya rezim Presiden Soeharto pada tahun 1998, menandai lahirnya era Reformasi, menghadirkan ruang yang lebih luas bagi elite Kesultanan Ternate untuk mengekspresikan keberadaan dan peran yang sebelumnya terkungkung dominasi pemerintah pusat. Munculnya Sultan Mudafar Syah sebagai kandidat calon Gubernur Maluku Utara pada 2001/2002, dapat dilihat sebagai pertaruhan untuk mempertahangkan keunggulan kebangsawanan Ternate dari munculnya dominasi baru diluar elite kesultanan.Strategi ini merupakan upaya yang ditempuh elite kesultanan agar tetap terakomodasikan secara institusional ke dalam panggung politik pemerintahan formal.

Gagalnya Sultan Mudafar Syah dalam pencalonannya sebagai Gubernur Maluku Utara 2002, bukan karena "kekalahan" tetapi karena intervensi pemerintah pusat dan dukungan politik Partai Golkar terhadap figur lain, ternyata tidak menyurutkan Sultan Mudafar Syah untuk berkiprah dalam pentas politik. Kekecewaaannya terhadap Golkar kemudian diarahkan untuk mendukung Partai Demokrasi Kebangsaan (PDK). Di pakainya PDK sebagai mesin politiknya yang baru, ternyata membuahkan hasil sehingga mengantarkannya sebagai anggota DPR RI periode 2004-2009. Terpilihnya Sultan Mudafar Syah sebagai anggota DPR RI tersebut,mengindikasikan sepanjang karier politiknya tidak mengalami "pasang surut".

Sebagai sebuah realitas sejarah, kemampuan bertahannya Sultan Ternate dalam panggung politik lokal sejak pasca kemerdekaan hingga era Reformasi, menunjukan bahwa mereka memiliki posisi politik sebagai pusat anutan di tengahtengah kehidupan masyarakat. Kemampuan bertahan ini, banyak di pengaruhi oleh 
kepercayaan masyarakat bahwa kelompok bangsawanlah yang berhak memerintah yang diperoleh lewat legitimasi geonologis. Legitimasi ini di sosialisasikan dalam berbagai upacara-upacara istana. Sosialisasi yang terus menerus ini pada gilirannya menghasilkan suatu kepercayaan masyarakat Ternate tentang kelebihan dan keistimewaan para sultan, sehingga melahirkan rasa patuh dan kehadiraanya dapat memberi ketentraman dan kesejahtaraan masyarakat.Disamping itu, keterampilan politik setiap sultan yang dimainkan dalam setiap rezim turut memperkuat eksistensinya dalam ranah politik lokal.

\section{DAFTAR PUSTAKA}

AAG. Ari Dwipayana, Bangsawan dan Kuasa Kembalinya Para Ningrat di Dua Kota. (Yogyakarta, IRE Press, 2004).

Ben Anderson, (eds), Demokrasi dan Konflik yang Mengakar: Sejumlah Pilihan untuk Negosiator. (Jakarta: Penerbit Antara IDEA, 2002).

David Henley, et al., Adat Dalam Politik Indonesia. (Jakarta: Yayasan Obor Indonesia, 2010).

Fachry Ammari dan J.W. Siokona, Ternate, Kelahiran dan Sejarah Sebuah Kota. (Ternate: Pemda Kota Ternate, 2003).

Gerry van Klinken, Perang Kota Kecil Kekerasan Komunal dan Demokratisasi di Indonesia. Jakarta: KITLV, 2007.

Hamid Kotambunan, Perjuangan Rakyat Maluku Utara Membebaskan Diri dari Kolonialisme. (Jakarta: Gamalama Media), hlm. 12-14. 2007).

Henk Schulte Nordholt, et.al. (ed), Politik Lokal di Indonesia.(Jakarta: KITLV,

J. Mansur. "Naskah Pengusulan Tingkat I Provinsi Maluku Utara Dewan Perwakilan Gotong Royong Daerah Tingkat II Maluku Utara”.Ternate, 1964. Tanpa Penerbit.

Maryanto Wahyu Tryatmoko, "Pemekaran Wilayah dan Pertarungan Elite Lokal di Maluku Utara, dalam Jurnal LIPI Jilid XXXI, No 1, 2005.

Muchtar Nurhasim, et. al, Konflik Antar Elit Lokal dalam Pemelihan Kepala Daerah: Kasus Maluku Utara, Jawa Timur dan Kalimantan Tengah. (Jakarta: LIPI, 2003).

Mudaffar Syah, Eksistensi Kesultanan Ternate dalam Sistem Tatanegara Republik Indonesia. (Ternate : Goheba, 2009).

Patrick Barron, et,al, Seusai Perang Komunal: Memahami Kekerasan PascaKonflik di Indonesia Timur dan Upaya Penanganannya. Yogyakarta: CSPS Books, 2012.

Purwo Santoso " Merajut Kohesi Nasional: Etno-nasionalisme dan Otonomi daerah" dalam Jurnal Ilmu Sosial da Ilmu Politik. Vol. 4, No 3, Maret 2001.

Rustam Hasim, Sultan dalam Sejarah Politik Ternate, 1945-2002. Ternate: LepKhair, 2018.

Rustam Hasim dan Mustafa Mansur, "Sultan Ternate Iskandar Djabir Syah: Dari Konperensi Malino Hingga Menjadi Menteri Dalam Negeri Negara 
Indonesia Timur (NIT) 1946-1950". Jurnal ETNOHISTORI Vol.II. No.1. April 2015. Fakultas Sastra, Universitas Khairun Ternate.

R. Siti Zuhro, et,al. Demokrasi Lokal Peran Aktor Dalam Demokratisasi. (Yogyakarta: Ombak, 2009).

Rusdi J. Abbbas, Demokrasi di Aras Lokal Praktek Politik Elite Lokal di Maluku Utara.Yogyakarta: Cerah Media, 2012.

Tabloid Parada. Ternate, edisi 2, tanggal 3-20 Desember 2008. 